\title{
Pre-service English Teachers' Strategies in Incorporating Character Education during the Teaching Practice Program at UIN Antasari Banjarmasin
}

\author{
Raida Ashfihana \\ UIN Antasari Banjarmasin, Indonesia. E-mail: raidaasfihana@uin-antasari.ac.id
}

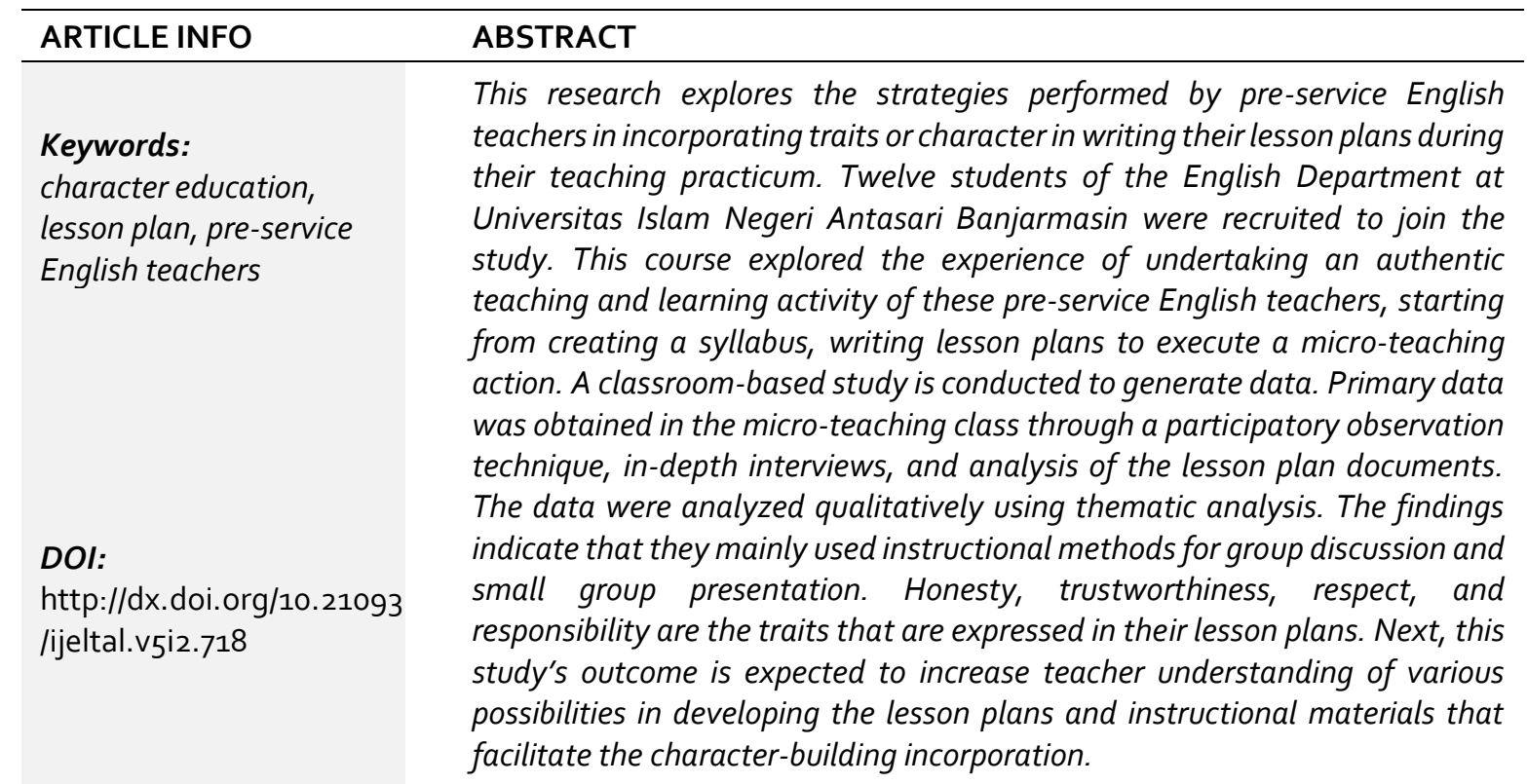

How to cite:

Ashfihana, Raida. (2021). Pre-service English Teachers' Strategies in Incorporating Character Education during the Teaching Practice Program at UIN Antasari Banjarmasin. Indonesian Journal of English Language Teaching and Applied Linguistics, 5(2), 309-322.

\section{Introduction}

The issue of character building has become part of teachers' and educational practitioners' discussions in recent years. The discourse about character education was formally brought up on National Education Day in 2010. Since then, through the Ministry of National Education, the government has conducted a series of seminars dealing with character education inclusion into the national curriculum. The implementation is planned to be undertaken gradually starting in 2011 in primary and secondary schools throughout provinces and continued to enact the 2013 curriculum (Iskandar, 2018). That is why the latest curriculum 
in Indonesia, the 2013 Curriculum, demands incorporating character or traits in developing the syllabus and writing the lesson plans. The need for character education has its roots in the nation's condition nowadays, which suffers from a multidimensional crisis. Many saddening cases are often heard in our society, ranging from the destructive, anarchist, and radical behaviours, such as riot, brawls, and vandalism done by a particular group of people, the decline of morals among teenagers, as seen in the case of free sex and abortion (based on data from BKKBN, as cited in Munip, 2009), until the subject of cheating during the National Examination and the most prevalent one today is the case of corruption of legislative members. Besides, it seems that the nation has forgotten the national motto of "Bhinneka Tunggal Ika", or unity in diversity, which could be seen from the phenomenon of the fading values of unity leading to the breaking apart of the nation.

National Education System Act (UU Sisdiknas) Article 3 (2010) has mentioned that national education's function is to develop and create nation character and civilization, to develop the students' maximum potency to be creative person, independent, and responsible democratic citizens. Character education is considered an essential part of the Long-Term Development Plan or Rencana Pembangunan Jangka Panjang 2005 - 2025. President Susilo Bambang Yudhoyono has emphasized the importance of character education in his speech on National Education Day in 2011. The Ministry of National Education has also taken some actions by conducting seminars, socialization/dissemination, and providing guidelines to implement the school program's character education. Based on Permendiknas No.23/2006 about Standard Kompetensi Kelulusan (SKL), it is noted that SKL contains the substance of character education either implicitly or explicitly (source: Dikti, 2010). Incorporating character education in the curriculum has created a challenge for teachers in designing the syllabus and materials (Muhibah, 2014). Ministry of Education through the Curriculum Center of the Research and Development Board only provides general guidelines on values or traits to be included in character education. It leaves the teachers to develop the topics or materials already outlined in each school subject's syllabus and standard competence (Trisiana \& Wartoyo, 2016).

The discussion on the inclusion of character education in teacher education was started about sixty years ago (Jordan et al., 2000). Berkowitz (1999) criticized that despite apparent goodwill to implement character education, training regarding its preparation was limited, especially for pre-service teachers. He stated that there was also limited space for character education in the pre-service curriculum. According to a survey conducted by Beachum (2005), most pre-service teachers had a positive attitude towards integrating character education into the curriculum and supporting its implementation. However, that positive attitude should also be accompanied by their ongoing commitment to continual learning, critical reflection, and growth in pre-service teachers (Mergler \& Spooner-Lane, 2012) if we want to enact character education in the pre-service teacher curriculum successfully. In recent studies, to achieve that purpose, some researchers and teacher educators implemented several strategies to integrate character education through improved learning design for preservice teachers (Sarkadi et al., 2020) and its inclusion in the teaching practice (Astuti et al., 2019).

Although those researches investigated many aspects of character education, little is known about its integration in the English language curriculum. For teachers of school subjects such as religion, civic education, or history, implementing character-based lessons is perhaps more 
manageable as the subjects already contain some materials about values and moral lessons. However, in the English language teaching context, it will be a little bit challenging because, sometimes, the character values mentioned in the curriculum are hardly connected with the teaching objectives of the English lesson (Ratih, 2017). Astuti et al. (2019) and Puspitasari (2020) found that teaching practice provides opportunities for pre-service teachers to gain knowledge and experience in designing lessons with the inclusion of character education. Astuti et al. and Puspitasari, who researched the integration of ${ }_{4} C^{\prime}$ 's characters, reported that the characters' values were reflected in the classroom activities and assessment.

Teaching practice is also a part of the English Department's curriculum in Universitas Islam Negeri (UIN) Antasari Banjarmasin. Colleges or universities with teacher education programs usually include this teaching practice as a compulsory course in their curriculum (Widodo \& Ferdiansyah, 2018; Yalcin Arslan, 2019). This course is generally offered in a four-year undergraduate study toward the end of the third year after passing several theoretical lectures in the previous semesters. Although this program is regularly conducted every year, it is not much known yet whether the participants have understood thoroughly the way to incorporate character education in their teaching and learning process, whether they have attempted to integrate it, what classroom activities have been designed to generate a character-based language lesson, what the outcomes are, and how practical the enactment is. Previous research on this topic and context was focused only on the pre-service teachers' teaching performance (Mufidah, 2019). Therefore, it was beneficial to closely investigate what the pre-service English teachers did with the materials and what strategies were used to link character education. To do so, this research's central question is, "how do the preservice English teachers incorporate character education in their teaching and learning process?" The sub-questions are: (1) What are the pre-service English teachers' strategies in developing the lesson plan so that it is character-based? (2) To what extent is character education incorporated into the lessons/classroom activities?

\section{Literature Review}

\subsection{Definition of Character}

The phrase of noble character is usually interpreted as good self-control of attitude. Many previous writers who studied character-building defined the character in mostly similar ways. Character is the way people express their inner and outward being that leads to the act of caring, respect, compassion, and all good attitudes to go with virtue (Agboola \& Tsai, 2012) and character in a virtuous state defined as an integrated package of perceptual, cognitive, motivational, and affective attributes. Next, people with good character may express good will, maintain a well-behaved act based on social ethics, and admire people's values and good qualities (Curren, 2017). From the material for character education training prepared by the Indonesian Ministry of National Education, a character is the personality or behavior of a person built due to internalization of various virtues that are then used as the base to think and act. Also, the interaction with other people will make the social character and the national character afterward.

Meanwhile, Mubarok (2019) and Anwar (2016) both agree that character is closely related to a person's good and bad behavior based on certain norms in a society. Mubarok (2019) stated that character is formed through a person's life, so it could change. A permanent character then will become a personality. Anwar (2016) emphasized that as the character is related to 
nature, a person could be assumed to have a character of his or her conduct suitable with moral norms. From all the definitions above, it can be concluded that character is an individual's good behavior and conduct according to the social standards formed through habitual action and learned through socialization and internalization process.

From the Muslim perspective, Anwar (2016) quoted Imam Ghazali, who stated that character is closer with akhlaq, which is the spontaneous act or behavior of a person, which is already ingrained in him/her. Besides, personality is the result of interaction among nafs, qalb, aqal, and bashirah. The character could be inherited from parents, formed through upbringing and life-long process, and internalization process of one's knowledge and experience. In a Muslim's life, the role model of noble character follows Prophet Muhammad SAW.

\subsection{The Scope of Character Education}

Character education has developed much earlier in several developed countries such as the U.S. and Canada. That is why various literature is available in these countries, ranging from government documents to research papers. Schools already have programs, and multiple books for guidelines are already available. Asia, Japan, and Korea are among countries that have already implemented character education. In some literature, it is found that character education should be differentiated from moral education. It is because moral education only teaches what is right and wrong.

In contrast, character education is intended to develop human qualities and provide an effective solution to academic and social problems (Lickona, 2010). Winton (2010) defined character education as the real effort by schools to teach moral and good virtues to students". Similarly, Character Education Partnership (CEP), which develops 11 principles for effective character education in the U.S., defined character education as the attempt to build a good and noble attitude to young people to be widely affirmed across different cultures' ethical norms. Character education is intended to minimize or prevent destructive behavior and lead the young generation to conduct the proper manner based on values.

In Indonesia, through the Curriculum Center of the Research and Development Board, the Ministry of National Education has prepared a guideline in which character education is combined with cultural education. That is why the scope of character education in Indonesia, though quite similar to the definition above, is somewhat broader than any kind of education which develops moral values and nation character embedded in the Indonesian students. Therefore, they could apply those moral values in their daily lives as religious, nationalist, productive, and creative citizens. The cultural and moral values which underlie character education in Indonesia should be developed from four sources: religion, Pancasila, culture, and the objective of national education. From these four sources, eighteen characters or traits are generated. They are: 1) religious, 2) honest, 3) tolerant, 4) disciplined, 5) hardworking, 6) creative, 7) independent, 8) democratic, 9) curiosity, 10) spirit of the nation, 11) patriotic, 12) appreciate achievement, 13) friendly/communicative, 14) love peace, 15) eager to read, 16) care to the environment, 17) care to the society, and 18) responsible (Kementerian Pendidikan Nasional, 2011). It seems such a long list of values; however, it is suggested that school and teacher do not need to take all of them in the implementation. Instead, they may adopt those values depending on the school's situation and condition, what is required for the local community, and what is outlined in each school subject's standard competence. 


\subsection{Previous Research on Character Education}

Waters \& Russell (2014) have investigated the efficacy of personal and the general teaching of 130 pre-service teachers in Florida. They used the Character Education Efficacy Belief Instrument (CEEBI) by Milson \& Mehlig (2002). The findings contributed insight into the teacher preparation program that includes character building in their curriculum. Dealing with the lesson plan integration with character building, Temiz (2019) has conducted a study in developing a model of the lesson plan in which the character education is integrated into this model. The participants of this study are five teachers teaching in primary education, two psychological counseling expertise, and two elementary education department academicians. The findings revealed that most participants give positive feedback toward the developed model, and the lesson plan model will be used as a future research project plan.

Many researchers have also conducted the use of teaching aids in building the students' character with satisfying research findings. Turan \& Ulutas (2016) have investigated the implementation of using picture storybooks in integrating character education and the teachers' perspectives in using this tool. Two hundred forty-five preschool teachers in Turkey used this media. The results show that preschool teachers have a positive attitude toward using picture storybooks in integrating character education. Yet, they are still partly competent in using it in their classroom activities-the suggestion made on providing books of literature and training on incorporating character-building into a preschool teaching program.

Regarding the teaching of character education to college students, Novianti (2017) has conducted a study in this education level using English bildungsromans teaching aids. A number of 35 sixth-semester students majoring English Literature program in Indonesia were taken as participants of this study. The research subjects were assigned to find the virtues of the bildungsromans Jane Eyre story. However, only a few of them could get insight into the novel virtues, but this media could still promote character education teaching, especially for college students.

\subsection{Integrating Character Education in School Curriculum: Opportunity and Challenges for Teachers}

Compared to other countries, Indonesia has vast potential to implement character education successfully. This fact is based on two major factors: first, Indonesian people already have distinct character traits and values inherited from our ancestors and have become the nation philosophy, i.e., Pancasila; and second, Indonesia is a religious country comprising Muslims as the majority. These factors should open up an opportunity for successful characterbuilding integration. As stated in the guidelines, religion is the first value on which the practice of character education should be based. It is because Indonesia is not a secular country; instead, in Indonesia, the citizens' lives are near related to the norms of religion, or in other words, the acts of the people should be based on the teaching of the faith (Kementerian Pendidikan Nasional, 2011). It means religion becomes the priority, and religious values should be used in character education. Here, educational practitioners are allowed to develop the lesson materials so that it includes some spiritual matters. The fact that Islam is the majority, with nearly $80 \%$ of the Indonesian citizens are Muslims, also allows educators to apply the Islamic values and integrate them with the character education at schools. 
The challenge faced by teachers is the fact that the Indonesian school curriculum is already overloaded. It would undoubtedly require hard work to design character-based lesson materials and prepare the assessment and evaluation rubrics. Perhaps, a solution offered by Stiff-Williams (2010) to fuse the teaching of character with the routine instruction of curriculum standards could be considered. The suggested five steps for achieving the incorporation of character building in education are:

1) Define the traits, character, and moral values based on the consensus of the community.

2) Educate teachers to analyze the minimum teaching target to practice incorporating the character into their teaching.

3) Facilitate teachers' training in designing lesson plan units that meet the curriculum standards and character-building incorporation.

4) Support teachers in the character-building incorporation to promote the learning experiences of character education development.

5) Motivate teachers to use performance-based assessments that may assess the students' character development effectively.

Our educational practitioners might adopt these steps and modify them following the Indonesian context. As a matter, the first two steps regarding the identification and guidance of character education have already been implemented. It is the last three steps that still need to be developed. Besides, the character or traits that can be embedded in English lessons are friendly, communicative, care to the society, curiosity, democracy, honesty and trustworthiness, independent, hardworking, disciplined, and eager to read.

\section{Research Methodology}

\subsection{Participants}

This research took place in a micro-teaching class in the English Department, Universitas Islam Negeri Antasari Banjarmasin, South Kalimantan, Indonesia. It had six intensive meetings in total, which took 4 hours per session. Twelve students got involved as research participants. They were the English Department's sixth-semester students taking the PPL 1 (micro-teaching) program As the nature of qualitative research is to gain vivid, detailed data from a small number of participants, it is expected that the participants can reach between 8-12 students. The method used was a classroom-based study with a participatory observation technique supported by field notes and focus group interviews (Creswell \& Creswell, 2018). Kral (2014) pinpointed that when a participatory qualitative method was administered to analyze data, the researcher and participants become co-investigators. Both parties were involved in collecting and analyzing the data.

As noted earlier, the researcher managed twelve student-teachers of the English Education Department at UIN Antasari Banjarmasin as the research participants. The students were seven females and five males. The twelve students' pseudonyms were Andi (male), Satria (male), Timah (female), Sandi (male), Handi (male), Diah (female), Dian (female), Santi (female), Ati (female), Wahdah (female), Amir (male), and Halimatus (female). Table 1 presents demographic information regarding the age and sex of the participants. 
Table 1. Demographic information of the participants

\begin{tabular}{llll}
\hline No & Respondent & Age (years old) & Male/ Female \\
\hline 1 & Andi & 20 & Male \\
2 & Satria & 19 & Male \\
3 & Timah & 20 & Female \\
4 & Sandi & 19 & Male \\
5 & Handi & 20 & Male \\
6 & Diah & 20 & Female \\
7 & Dian & 21 & Female \\
8 & Santi & 20 & Female \\
9 & Ati & 19 & Female \\
10 & Wahdah & 19 & Female \\
11 & Amir & 21 & Male \\
12 & Halimatus & 20 & Female \\
\hline
\end{tabular}

The information derived from Table 1 indicated that there was no slight difference in age among the students. The achievement test result before the research implementation also showed that they share mostly similar English language competencies. The first data investigated in this research was the implementation of character building in terms of the pre-service English teachers' teaching strategies during the micro-teaching class. The second one was the lesson plan designed by them before their teaching practices. Prior to conducting the teaching and learning process, the pre-service English teachers needed to efficiently and effectively write the lesson plan. Next, the lesson plan was used to check the type of traits that are incorporated into it. From these representative students, the researcher could gather character-building incorporation data along with specific materials and strategies used by the research participants.

\subsection{Instruments}

The researcher used three data collection techniques to gather data in this research: in-depth interviews, observation, and documentary. An in-depth interview has been conducted to gain information about the students' perception of character education and their previous knowledge of character education. The interview is semi-structured, in which the researcher prepares a set of questions along with the possible probes prior to the interview. It consists of inquiries related to the implementation of character education in English teaching and learning. For the observation technique, a participatory observation is conducted during the class. The researcher observes the teaching and learning process using an observation sheet and takes notes during the observation. It is intended to examine the pre-service English teachers' strategies in incorporating character building into the teaching and learning process, types of classroom activities designed to generate a character-based language lesson, and the lesson plan's outcomes as seen from the students' active participation during the study. The last technique is the documentary. The documents being checked including the syllabus, the teaching materials such as textbooks, supplementary text, and teaching aids, the pre-service teachers' lesson plans, and the evaluation rubric (if any). These documents are necessary to see the link between the designed material and the implementation. 


\subsection{Data Analysis Procedures}

The interview results are analyzed using descriptive and thematic analysis (Braun \& Clarke, 2006) to determine any trends or common themes among the responses. Meanwhile, the observation results are also analyzed descriptively to examine whether the pre-service English teachers' materials and strategies in embedding traits that students need to apply during the English lesson are successful or not and see whether the lesson objectives are achieved as intended. Documents are examined to see whether the lesson's character or traits are clear and relevant to the classroom activities.

\section{Findings and Discussion}

\subsection{The Pre-service English Teachers' Strategies in Developing the Lesson Plan}

This study's primary data deal with the pre-service English teachers' strategies in designing lesson plans and the traits embedded in their material development. The data analysis result gathered from the in-depth interview, classroom observation, and document study showed that most pre-service English teachers usually asked the students to do self-performance and work in a small group. Amir and Timah expressed their feelings dealing with this finding as to the following.

"I prefer a lot to set my students in a small group doing a certain task. I will be able to see their communicative or friendly trait by doing so". (Amir, interview data)

"I usually set my lesson plan using a project-based learning approach. I monitor their tolerant and responsibility while completing the project work". (Timah, interview data)

These data reveal that Amir and Timah considered a group or teamwork a vital activity to be included in the learning process to integrate characters, such as communicative/friendly, tolerant, and responsible. It shows their understanding that group work can facilitate the students to interact with their friends (communicative/friendly), to respect other opinions (tolerant), and to share their tasks (responsibility). The researcher also noticed that the participants' lesson plan gave a broad interest in having the students do group discussions and prepare a short group presentation. The present findings support previous research, which found that encouraging the students to collaborate in project work helps improve the students' creativity (Puspitasari, 2020), content knowledge (Ke, 2010) and increase lowachieving and less-confident students' performance (Ravitz, Hixson, English, \& Mergendoller, 2012; O'Sullivan et al., 2017). Besides, Timah's ideas to monitor the students during the project work is in line with Stiff-Williams (2010) recommendation that an effective way to assess students' character development is through ongoing assessment.

Dealing with the strategies in developing the lesson plan, the researcher observed that the micro-teaching students tended to create their own teaching material that met the learners' needs. They combined the local substance with the English material. For example, there was a lesson plan from one research participant talking about celebration. This pre-service English teacher named Satria, put the text entitled "Baayun Mulud," which was closed to Banjarese culture. In the in-depth interview, he mentioned that he chose this text instead of the text available on published textbooks simply because he thought his students would easily understand this reading text. He also felt it easy to integrate religious and respect traits through this text. 
"Most of the students are Banjarese, and they are accustomed to the Banjarese culture. The other students who come from different tribes would like to learn and respect the cultural tradition as well. I chose "Baayun Mulud" since it delivers the religious aspect of life." (Satria, interview data)

What Satria did in selecting the local wisdom as the teaching materials is in accordance with the Indonesian Ministry of Education and Culture (2011) guideline for character education that Pancasila and religion's values should become the priority in implementing the character-based lesson. Indonesia is a country whose rich cultural and local values can be adapted into the teaching materials. Satria's action in choosing "Baayun Mulud" also supports Qoyyimah's (2016) findings that the implementation of character education in the classroom is dominated by the communities and the teacher's preferred values of religiosity. Satria chose "Baayun Mulud" because he knew that most of the students were Banjarese, and a Banjarese culture-related topic would be interesting for students, either for the local students or the students from other tribes. This finding also points out that selecting teaching materials reflects the students' effort in incorporating character education, as discussed in Ratih's research (2017). Satria decided to take that topic because it would facilitate the students to learn the religious aspect contained in that tradition.

The researcher observed that the character being taught is apparent in the research participants' lesson plan. They mentioned the traits they want to explore to their students and tried to relate with the teaching objectives suggested in the curriculum or developed syllabus.

"I tried to follow the curriculum and syllabus guideline in writing my lesson plan and insert the character values into it. After that, I will consult with my supervisor whether or not it was correct." (Halimatus, interview data)

Halimatus' $s$ statement implies that pre-service teachers tend to directly adapt the curriculum's guideline into their syllabus, including the character values should be taught for the student. Regarding this practice, the teacher educator or the micro-teaching supervisor should facilitate the pre-service teacher to select character values that meet the objectives as well as the activities in the classroom. This is important since incorporating character education in English teaching is attractive as well as challenging (Aghni et al., 2020). Mergler and Spooner-Lane (2012) recommend that a character-based lesson in the teaching practice should have a model to follow or end with a failure. The supervisor should accompany the pre-service teachers to appropriately select the character values and assess whether the learning activities reflect the implementation of those values. Supporting this finding, Mufidah (2019) also found that supervisors' role in a teaching practice program was immensely important because the pre-service teachers could make some improvements in their teaching performance after getting feedback from them. Therefore, Mufidah advised that teaching practice supervisors should give detailed feedback to benefit the students' professional development. In implementing a character-based lesson, it is also recommended that supervisors also guide the pre-service teachers to make a reflection after teaching. It will help them to assess the effectiveness of their character values lesson. 


\subsection{Character Building Incorporation into the Classroom Activities}

The in-depth interview and participatory observation techniques applied to the research participants showed that their common traits are honesty, respect, and responsibility. They incorporated these traits using various classroom activities such as working in small teams and conducting group presentations. The interviewees said that this classroom activity was assumed to boost the students' honesty, respect, and responsibility for their assigned tasks. Before the classroom activities, the participant determined the character incorporated in their lesson. The development of the students' character was observed by using a rubric. In this rubric, the pre-service teacher gave a checklist on the character showed up by the students during the teamwork. The sample of the rubric is presented in Table 2.

Table 2. Sample of Character-Values Rubric

\begin{tabular}{|l|c|c|c|}
\hline \multicolumn{1}{|c|}{ Name } & \multicolumn{3}{c|}{ Character-Values Evaluated } \\
\hline & Honesty & Respect & Responsibility \\
\hline Ali & $\sqrt{ }$ & $\sqrt{ }$ & \\
\hline Ani & $\sqrt{ }$ & $\sqrt{ }$ & $\sqrt{ }$ \\
\hline
\end{tabular}

The rubric was made as simple as possible, so the pre-service teacher can easily use it. They only needed to define the character being observed; for example, responsibility refers to the students' willingness and effort to complete the task given to him/her during the teamwork. If the student completed the task, it meant that he/she was a responsible person. Drawing from Berkowitz' study (1999), defining the character values to observe is important since it is sometimes an obstacle for the teacher to assess if it is not clearly stated. This finding is following Puspitasari's study (2020) that the inclusion of character-based education is not only implemented in the learning activities but also possible in the assessment.

Besides the characters mentioned above, the team or group work activities also promote other character values. Ati, for example, mentions that asking students to do presentations would be able to improve their creativity as well as independent characteristics.

I usually invite my students to create posters or online Instagram stories to build their creativity because I notice that being creative students is also a trait that should be embedded in my lesson plan. (Ati, interview data)

Creativity and independence are two characters mandated in the objectives of national education (2011). Ati's selection of learning activities reflects her understanding that promoting character values should consider the students' interest (Mergler \& Spooner-Lane, 2012). Instagram is a popular social media that is now mainly used by most students, so it will trigger them to be more creative. Since the students were familiar with the apps, they will also be more independent in completing the task to minimize their dependency on the teacher. Therefore, based on this finding, we can conclude that the same kind of learning activity can promote more than one or two traits if the teacher can vary the values inserted in the teaching and learning process.

Ati's effort to integrate technology into her lesson also reveals that integrating ICT into a character-based lesson can be a good alternative for teaching character values in the classroom. Referring to Anas \& Musdariah (2018) research, the use of technology in teaching can help the pre-service teacher to have a better and effective strategy. However, Emaliana 
\& Inayati (2017) state that providing the pre-service teacher with ICT knowledge and skills is insufficient. It is also necessary to equip them with pedagogical content knowledge so that the ICT integration will result in a better learning outcome. If the teacher only has ICT knowledge, the focus of learning will on the use of technology. In Ati's case, she selected appropriate ICT tools and activities that could promote student creativity and independence.

Next, based on the observation, it shows that the pre-service teachers focus on specific activities suggested in the curriculum to teach particular characters or traits reflected in their lesson plan. Table 3 describes the language skills and language activities, which are conducted by the students during the teaching practice and related to several traits.

Table 3. Language skill and language activities which is related to several traits

\begin{tabular}{|c|c|c|c|}
\hline No & Language Skill & Classroom Activities/ Strategies & Traits/Character \\
\hline 1 & $\begin{array}{l}\text { Listening - } \\
\text { Speaking }\end{array}$ & $\begin{array}{l}\text { - Storytelling } \\
\text { - Roleplay } \\
\text { - Class discussion on a particular behavior }\end{array}$ & $\begin{array}{l}\text { Friendly, curiosity, } \\
\text { tolerant, responsible }\end{array}$ \\
\hline 2 & Reading & $\begin{array}{l}\text { - Identifying specific traits of a character } \\
\text { in a story/ text } \\
\text { - Understanding the moral of a story }\end{array}$ & $\begin{array}{l}\text { Honest, trustworthy, } \\
\text { eagerness to read, } \\
\text { religious }\end{array}$ \\
\hline 3 & Writing & - Creating a story on a particular trait & Creative, respect \\
\hline
\end{tabular}

The findings showed that pre-service English teachers had incorporated character education into the teaching of four language skills. Besides, the data generated from the lesson plans highlight the traits of friendly, curious, tolerant, responsible, honest, trustworthy, eagerness to read, religious, creativity, and respect had been embedded in the teaching of listening, speaking, reading, and also writing skill, respectively. In the interview, the participants also noticed that they had tried their best to incorporate character education into their teaching, either explicitly or implicitly. Their answer reflects that they are aware that the incorporation of character education requires them to implement various teaching strategies, as was also revealed in the previous research (Sarkadi et al., 2020).

However, they also admitted that sometimes it was hard to manage the character-based lesson's integration since they only had 15 minutes to perform. This kind of student's complaint is also found in previous research. Mufidah (2019) argues that 15 minutes are to short for students to practice, especially when they want to use media such as video, song, or short film. In the present study, the students felt that preparing performance-based classroom activities, such as role-play or story creation, frequently require more than the time allotment provided. They were afraid that if the supervisor would consider it as a failure in setting the time management. Therefore, the choice of activities, according to them, become limited because of this constraint.

Regarding that time constraint problem, the role of the supervisor is essential. The supervisor and the pre-service teacher should negotiate the activities and the time allotment. It is the supervisor's role as the facilitator to ensure that pre-service teachers can perform within a proper time to achieve the learning objectives and integrate and observe the character values inserted in their teaching practice. 


\section{Conclusion}

\subsection{Summary}

The data collection and analysis results have shown that pre-service English teachers have performed various strategies and activities to incorporate character education into their lesson plans and teaching enactment. In developing the lesson plan, the pre-service teachers put their effort into integrating the character values by carefully selecting the learning activities and materials. They also consulted the lesson plan to the supervisor, so they got feedback prior to the implementation. This consultation is important because character education requires careful planning and continual learning. The character or traits the lesson plan has in common are responsible, honesty, trustworthiness, respect, and religious.

Next, character-based education also reflected in classroom activities. Group work, storytelling, roleplay, class discussion, identification of traits in the text, and story creation are activities conducted by the students to promote the incorporation of traits in the lessons. The participants showed their ability in assessing the traits by using a rubric during the classroom activities. The data also revealed that some participants were able to vary the use of one activity (group work) to promote various character values. The present findings conclude that the Teaching Practice program is potential as an alternative for training preservice teachers to incorporate character education in the English language teaching context.

\subsection{Limitation and Recommendation}

Since this research is conducted in a small testing group, a Teaching Practice 1 or a microteaching course, it is strongly suggested to do further study at schools using real English teachers and students as the research participants. It might show different results because the research participants are pre-service teachers who have never taught in an actual classroom setting. Another consideration is that the participants who acted as the students in this Teaching Practice I course are sixth-semester students at an intermediate English level. It will show different results for the experienced teachers at the Junior or Senior high school level. Nevertheless, since this research aims to find out strategies used in incorporating character building in lesson plans and its implementation, we may say that this present research's objectives have been achieved as intended.

\section{References}

Agboola, A., \& Tsai, K. C. (2012). Bring character education into classroom. European Journal of Educational Research, 1(2), 163-170. https://doi.org/10.12973/eu-jer.1.2.163

Aghni, L. A., Vianty, M., \& Petrus, I. (2020). Character education in English subject: Teachers' perceptions and strategies. JEES (Journal of English Educators Society), 5(2), 127-134. https://doi.org/10.21070/jees.v5i2.420

Anas, I., \& Musdariah, A. (2018). Being an E-Teacher: Preparing the ESL Teacher to Teach English with Technology. Journal of English Language Teaching and Linguistics, 3(1), 4156. https://doi.org/10.21462/jeltl.v3i1.102

Anwar, S. (2016). Peran Pendidikan Agama Islam Dalam Membentuk Karakter Bangsa. Jurnal Pendidikan Islam, 7(November), 157-169.

Astuti, A. P., Aziz, A., Sumarti, S. S., \& Bharati, D. A. L. (2019). Preparing 21st Century Teachers: Implementation of ${ }_{4} \mathrm{C}$ Character's Pre-service Teacher through Teaching 
Practice. Journal of Physics: Conference Series, 1233(1). https://doi.org/10.1088/1742$6596 / 1233 / 1 / 012109$

Beachum, F. D. (2005). Pre-service Teacher's Perceptions of Character Education. MidWestern Educational Researcher, 18(4), 45-52.

Berkowitz, M. W. (1999). Obstacles to Teacher Training in Character education. Action in Teacher Education, 20(4), 1-10. https://doi.org/10.4324/9781315179506-2

Braun, V., \& Clarke, V. (2006). Using thematic analysis in psychology. Qualitative Research in Psychology, 3(2), 77-101. https://doi.org/10.1191/1478088706qpo63oa

Creswell, J. W., \& Creswell, J. D. (2018). Research Design: Qualitative, Quantitative, and Mixed Methods Approaches (5th ed.). Sage. https://doi.org/10.1017/CBO9781107415324.004

Curren, R. (2017). Why character education? Impact, 2017(24), 1-44. https://doi.org/10.1111/2048-416x.2017.12004.x

Emaliana, I., \& Inayati, D. (2017). The Relationship among Pre-Service EFL Teachers' Beliefs about Language Learning, Pedagogical Beliefs, and Beliefs about ICT Integration. Dinamika Ilmu, 17(1), 83-99. https://doi.org/10.21093/di.v17i1.664

Iskandar, I. (2018). School-Based EFL Curriculum Implementation in Indonesian Primary School. Asian EFL Journal, 20(4), 261.

Jordan, K. F., Metha, A., \& Webb, D. L. (2000). Foundations of American education (3rd editio). Prentice-Hall.

Ke, L. (2010). Project-based College English : An Approach to Teaching Non-English Majors. Journal of Applied Linguistics, 99-112.

Kementerian Pendidikan Nasional. (2011). Pedoman Pelaksanaan Pendidikan Karakter. In Kementerian Pendidikan Nasional. Badan Penelitian dan Pengembangan Pusat Kurikulum dan Perbukuan.

Kral, M. J. (2014). The Relational Motif in Participatory Qualitative Research. Qualitative Inquiry, 20(2), 144-150. https://doi.org/10.1177/1077800413510871

Lickona, T. (2010). Character Education Partnership. Education.

Mergler, A. G., \& Spooner-Lane, R. (2012). What pre-service teachers need to know to be effective at values-based education. Australian Journal of Teacher Education, 37(8), 6681. https://doi.org/10.14221/ajte.2012v37n8.5

Milson, A. J., \& Mehlig, L. M. (2002). Elementary school teachers' sense of efficacy for character education. Journal of Educational Research, 96(1), 47-53. https://doi.org/10.1080/00220670209598790

Mubarok, A. (2019). Implementation of Three Characters Education Design to Improve the Quality Of Academic Civitas College. 4(2), 214-221.

Mufidah, N. (2019). The Development of Pre-Service Teachers' Teaching Performance in the Teaching Practice Program at English Department of State Islamic University of Antasari Banjarmasin. Dinamika Ilmu, 19(1), 97-114. https://doi.org/10.21093/di.v19i1.1469

Muhibah, S. (2014). Curriculum Development Model Islam Character Based Education ( Studies Analysis In SMKN 2 Pandeglang Banten ). International Journal of Scientific and Technology Research, 3(7), 164-169.

Novianti, N. (2017). Teaching character education to college students using bildungsromans. International Journal of Instruction, 10(4), 255-272. https://doi.org/10.12973/iji.2017.10415a

O'Sullivan, D., Krewer, F., \& Frankl, G. (2017). Technology enhanced collaborative learning 
using a project-based learning management system. International Journal of Technology Enhanced Learning, 9(1), 14-36. https://doi.org/10.1504/IJTEL.2017.084085

Puspitasari, E. (2020). Project-based Learning Implementation to Cultivate Pre-service English Teachers ' 21st Century Skills. IJELTAL (Indonesian Journal of English Language Teaching and Applied Linguistics), 5(1), 191-203.

Qoyyimah, U. (2016). Inculcating character education through EFL teaching in Indonesian $\begin{array}{llll}\text { state schools. } \quad \text { Pedagogies, } & \text { 11(2), }\end{array}$ https://doi.org/10.1080/1554480X.2016.1165618

Ratih, I. A. M. (2017). The Analysis of Classroom Character Education in English Lessons Based on the 2013 Curriculum. Journal of Psychology and Instructions, 1(2), 97. https://doi.org/10.23887/jpai.v1i2.10365

Ravitz, J., Hixson, N., English, M., \& Mergendoller, J. (2012). Using project based learning to teach 21 st century skills: Findings from a statewide initiative. Annual Meetings of the American Educational Research Association., April, 1-9.

Sarkadi, Casmana, A. R., \& Rahmawati, Y. (2020). Improved learning design for pre-service teacher in a character education course. Universal Journal of Educational Research, 8(1), 212-224. https://doi.org/10.13189/ujer.2020.080126

Stiff-Williams, H. R. (2010). Widening the Lens to Teach Character Education Alongside Standards Curriculum. The Clearing House: A Journal of Educational Strategies, Issues and Ideas, 83(4), 115-120. https://doi.org/10.1080/00098651003653030

Temiz, N. (2019). A lesson plan model for character education in primary education. Educational Research and Reviews, 14(4), 130-139. https://doi.org/10.5897/err2018.3616

Trisiana, A., \& Wartoyo. (2016). Desain Pengembangan Model Pembelajaran Pendidikan Kewarganegaraan melalui Addie model Untuk Meningkatkan Karakter mahasiswa Di Universitas Slamet Riyadi Surakarta. PKn Progresif, 11(1), 312-330.

Turan, F., \& Ulutas, I. (2016). Using storybooks as a character education tools. Journal of Education and Practice, 7(15), 169-176.

Waters, S., \& Russell, W. B. (2014). Pre-service Secondary Teachers' Sense of Efficacy in Teaching Character Education. Journal of Education, 194(2), 45-54. https://doi.org/10.1177/002205741419400206

Widodo, H. P., \& Ferdiansyah, S. (2018). Engaging student teachers in video-mediated selfreflection in teaching practica. Routledge International Handbook of Schools and Schooling in Asia, 11237, 922-934. https://doi.org/10.4324/9781315694382-89

Winton, S. (2010). Character education, new media, and political spectacle. Journal of Education Policy, 25(3), 349-367. https://doi.org/10.1080/02680931003624532

Yalcin Arslan, F. (2019). Reflection in pre-service teacher education: exploring the nature of four EFL pre-service teachers' reflections. Reflective Practice, 20(1), 111-124. https://doi.org/10.1080/14623943.2018.1564652 